\title{
Exploring the Effects of Professional Development for the Interactive Whiteboard on Teachers' Technology Self-Efficacy
}

\author{
Joshua D. DeSantis \\ York College of Pennsylvania, York, PA, USA
}

idesant1@ycp.edu

\section{Executive Summary}

Identifying means of assisting teachers in integrating technology during their instruction is becoming more important as the rate new technologies enter the classroom accelerates. The primary means of helping in-service teachers employ new technologies in their classrooms is frequently professional development. Unfortunately, professional development offered to many teachers is ineffective. It has been posited that professional development can be made more effective by emphasizing one specific technology for an extended period of time, including opportunities for teachers to learn from each other in localized contexts, and organizing the learning in ways calculated to help teachers build technology self-efficacy (DeSantis, 2012).

This paper shares the results of a research project conducted to determine if professional development with these attributes assists teachers with developing the skills required to integrate technology during instruction. This project involved the creation of a professional development program with the characteristics described in the literature as being most effective (Brinkerhoff, 2006; Cantrell \& Hughes, 2008; DeSantis, 2012; Doppelt et al., 2009; Walker et al., 2011). This mixed-methods and design-based study identifies changes in technology self-efficacy and technological, pedagogical, and content knowledge among forty-one teachers following their participation in sustained, collaborative, and scaffolded professional development for one rapidlyembraced technology, the interactive whiteboard. The possession of technology self-efficacy assists teachers in adopting new technologies (Brinkerhoff, 2006; Holden \& Rada, 2011; Tschannen-Moran \& McMaster, 2009; L. Wang, Ertmer, \& Newby, 2004). Technological, pedagogical, and content knowledge are indicators of teachers' abilities to utilize educational technologies during instruction (Mishra \& Koehler, 2006).

The results of this study indicate that teachers who participate in well-designed professional development are likely build technology self-efficacy and technological, pedagogical, and content

Material published as part of this publication, either on-line or in print, is copyrighted by the Informing Science Institute. Permission to make digital or paper copy of part or all of these works for personal or classroom use is granted without fee provided that the copies are not made or distributed for profit or commercial advantage AND that copies 1) bear this notice in full and 2) give the full citation on the first page. It is permissible to abstract these works so long as credit is given. To copy in all other cases or to republish or to post on a server or to redistribute to lists requires specific permission and payment of a fee. Contact Publisher@InformingScience.org to request redistribution permission. knowledge. Qualitative analysis of semi-structured participant interviews conducted with a random sample of participants in the study revealed that the professional development program under study was integral in this development. Participants were particularly affected by the opportunities to collaborate embedded within the professional development offering under study during this project. The results from this 
study help to confirm the value of well-designed professional development in assisting teachers tasked with incorporating technology-supported teaching techniques in their teaching.

Keywords: Design-based research, Interactive whiteboards, Professional development, Technological Pedagogical Content Knowledge (TPACK), Technology acceptance models, Technology self-efficacy

\section{Introduction}

The pedagogies employed by many teachers in the United States do not take full advantage of the opportunities made possible by emerging technologies. While teachers gradually integrated education technologies throughout the twentieth century (Lyons \& Plunckett, 2007), the rate of change has not kept pace with the digital revolution of the 1990s and early 2000s (Collins \& Halverson, 2010). The list of new classroom technologies is extensive and includes tablet computers, interactive whiteboards (IWBs), web 2.0 tools, social media, online gaming, and smart phones, with more becoming available every year (Cennamo, Ross, \& Ertmer, 2010). These new technologies offer educators capabilities that could allow them to radically transform how they help their students to learn new content and skills. Yet, school systems, and the teachers operating within them, are slow to change and the digital revolution has had only modest effects on classroom instruction (Buckenmeyer, 2010). One example, cited by Jacobs (2010), is the shift many in our society have made from relying on print forms of media in the 20th century to relying on digital and video forms of media in the 21 st century. This societal transition has not been accompanied by complementary changes in the forms of instruction employed in many of our schools, much to the detriment of students' readiness to live and work as digital citizens and participants in the 21st century economy (Collins \& Halverson, 2010; Jacobs, 2010; Wagner, 2012).

Teacher resistance to integrating technologies may be partly to blame (Hall, 2010). Most theories that describe technology use and diffusion suggest that receptivity to new technologies can be arrayed along a spectrum, with some advanced adopters embracing new technologies, moderate adopters using technology as a replacement for other functions, and some resisters who reject most new technologies (Davis, 1989; Hall \& Hord, 2010; Rogers, 1962; Venkatesh, Morris, Davis, \& Davis, 2003). While these models help to explain variations among teachers in how they integrate technologies, the existence of this technology adoption continuum makes it difficult to plan professional development that meets the diverse needs and interests of teachers in a school.

One means of changing these patterns of teachers' technology adoption is to improve the quality and effectiveness of teachers' professional development for education technologies by tailoring it to meet specific demands in local contexts. Unfortunately, professional development in the United States is frequently prescribed to teachers by administrators or policy makers to address perceived deficiencies in teachers' methods, is often disassociated from actual classroom contexts, and is generally not viewed favorably among in-service teachers (Hill, 2009). Professional development is also often associated with proscriptive professional development, which seeks to identify teaching practices that produce demonstrable results in student achievement on standardized tests then reward teachers who engage in these practices while punishing those that do not (Hanushek \& Rivkin, 2010; Measures of Effective Teaching Project, 2009; Whitehurst, 2010).

Distributed styles of professional development might provide a more effective foundation for helping teachers to integrate technology in their instruction. Distributed professional development encourages teacher leadership, collaboration, and autonomy (Darling-Hammond, 2010; Darling-Hammond \& Richardson, 2009; DuFour, 2004; Sergiovanni \& Starratt, 2006). This emphasis on teacher leadership implies that advocates of distributed professional development favor localized professional development, designed by teachers to address context-specific needs. 
The debate between advocates of proscriptive and distributed education professional development influences the forms of professional development currently offered to in-service teachers for education technologies. This article presents the findings of a study that might inform this debate and assist designers in creating professional development that helps teachers to integrate technology effectively in their instruction. This mixed-methods and design-based study was created to measure changes in teachers' technology self-efficacy following their participation in a distributed professional development program for the interactive whiteboard (IWB). These changes were recorded by administering an instrument designed for this study. This instrument measured participants' self-perceived IWB usefulness, IWB ease-of-use, IWB technological knowledge, IWB technological-pedagogical knowledge, and IWB technological-content knowledge. These categories of technology self-efficacy were first identified in Davis' (1989) Technology Acceptance Model (TAM) and Mishra and Koehler's (2006) Technological Pedagogical Content Knowledge (TPACK) theory.

Three questions were created to focus this effort: (1) Does participation in sustained, collaborative and scaffolded professional development affect the perception of usefulness, perception of knowledge, and technology self-efficacy regarding IWBs among participants? (2) Do differences exist in the technology self-efficacy for the use of IWBs among participants who joined in a daylong professional development workshop and monthly skills seminars and teachers who only participated in monthly skills seminars? (3) What do participants report regarding how their participation in sustained, collaborative, and scaffolded professional development for the IWB influenced their technology self-efficacy and their use of technology during instruction? The Interactive Whiteboard Technology Self Efficacy Survey (IWBTSE) was created to gather quantitative data used to answer questions one and two. Six semi-structured participant interview questions were administered to gather the qualitative data analyzed to answer question three.

\section{Literature Review}

\section{Principles of Effective Professional Development}

Whether the designer adopts methodological or distributed approaches to teacher learning, creating effective professional development requires thoughtful planning, committed leadership, resources, and time (DeSantis, 2012). Unfortunately, these resources are in short supply in many school districts in the United States. As a result, much of the professional development provided to teachers occurs during short-term workshops (Darling-Hammond \& Richardson, 2009; Hill, 2009). Detached from their classrooms, isolated from each other and bombarded by PowerPoint slides and lectures, many teachers have difficulty staying awake during professional development workshops, let alone learning anything that could help them reach their students (DeSantis, 2012). Designers that aspire to help teachers improve their instruction must first overcome the absence of significant sources of technology self-efficacy among many teachers and the presence of negative teacher perceptions about professional development (Hill, 2009).

Three guiding principles are shared by distributed professional development offerings in many American schools. They include (1) sustaining a cohesive and directed program of professional development over a period of months or years, (2) designing professional development that invites teacher collaboration and includes teachers in positions of leadership, and (3) scaffolding teachers' learning by ensuring they master basic skills before attempting more complicated tasks (DeSantis, 2012; Garet, Porter, Desimone, Birman, \& Yoon, 2001). By creating professional development that includes these characteristics, designers can maximize the teacher learning that occurs and increase the likelihood that the professional development has a positive effect on teachers' instruction. 


\section{Long-Term Professional Development}

Professional development is more effective when it is deeply embedded in a school's culture (Brinkerhoff, 2006; Doppelt et al., 2009). One important way for professional development designers to ensure this occurs is to maintain focused programs on specific topics over many months (DeSantis, 2012). According to Guskey \& Yoon (2009), "educators at all levels need just-in-time, job-embedded assistance as they struggle to adapt new curricula and new instructional practices to their unique classroom contexts" (p. 498). The ability to commit to just a few professional development themes was shown to have a measurable effect on the degree to which professional development programs affected pedagogical changes among teachers (Yoon, Duncan, Lee, Scarloss, \& Shapley, 2007). In turn, the positive effects on teachers' instruction developed during sustained professional development have been shown to boost students science achievement (Johnson, Kahle, \& Fargo, 2007), positively influence teachers' instructional habits (Perry, Dockett, \& Harley, 2007), and help teachers develop self-efficacy for their teaching practices (Cantrell \& Hughes, 2008). Together, these findings demonstrate the value of long-term professional development for teachers.

\section{Collaborative Professional Development}

Collaborative professional development includes structures that facilitate teacher interaction while achieving common goals and collective growth. Collaboration might take a variety of forms during professional development, including professional learning communities (DuFour, 2004) and assigning teachers roles as peer-coaches and mentors during professional development (Tschannen-Moran \& McMaster, 2009). While many professional development designers and policy-makers claim to value teacher collaboration and many teachers express a desire to collaborate during professional development, few professional development programs include structural opportunities for teachers to collaborate (Hill, 2009). Hierarchical administrative governance, isolated teacher planning schedules, and historical professional isolation conspire to inhibit professional development designers who desire to facilitate teacher collaboration during professional development (DuFour, 2011). These elements are frequently compounded by teachers' resistance to collaborative efforts out of fear that it could cause them to lose autonomy and the freedom to select their own instructional methods (Musanti \& Pence, 2010).

Despite these challenges, designers that include these characteristics in their professional development reap significant benefits (DeSantis, 2012). Teachers that participate in collaborative professional development report a higher degree of career satisfaction and are less likely to abandon the profession (Fulton \& Britton, 2011). Students of teachers who participate in collaborative professional development might also be more likely to score higher on standardized achievement benchmarks (Goddard, Goddard, \& Tschannen-Moran, 2007).

\section{Scaffolded Professional Development}

Scaffolded professional development design presents teachers with basic concepts first, then gradually increases the degree of difficulty of new information and activities. For example, teachers that are taught how to manipulate the size, shape, and color of an object using IWB software will be more successful in performing a more advanced task, like creating an interactive student activity using the IWB. Teacher actions during scaffolded professional development may be conceptualized as helping them to create trusses that bridge them from their current understandings and skill levels to more advanced competencies (Berk \& Winsler, 1995). Teachers that engage in some form of scaffolded professional development are more likely to retain the skills and content they learned during the program (Walker et al., 2011). Scaffolding professional development is an effective way for professional development designers to assist teachers in building self-efficacy for educational technologies (DeSantis, 2012). 


\section{Professional Development for Instructional Technology}

Ensuring that professional development incorporates these basic principles is particularly important when designing training for emerging instructional technologies. Teachers who use technology well embrace a philosophy that guides them to adopt new tools to enhance their instruction (Hixon \& Buckenmeyer, 2009). The possession of this philosophy can be measured by identifying teachers' technology self-efficacy (Holden \& Rada, 2011; L. Wang et al., 2004) and by determining teachers' possession of the technological, pedagogical, and content knowledge required to integrate a technology (Mishra \& Koehler, 2006). Teachers that maintain a high degree of technology self-efficacy are more likely to use new technologies during their instruction (DeSantis, 2012; Holden \& Rada, 2011; Overbaugh \& Lu, 2008). Similarly, teachers that possess elevated levels of TPACK are also better positioned to integrate new technologies in their classrooms (Mishra \& Koehler, 2006; Polly \& Brantley-Dias, 2009). Professional development designers can encourage teachers to learn new technologies by designing learning opportunities that foster the generation of technology self-efficacy and TPACK.

\section{Methodology}

The design-based research paradigm was used to carry out this research. Design-based research is a method of investigation that encourages researchers to actively participate in the design and implementation of the programs they study (F. Wang \& Hannafin, 2005). The design-based research paradigm combines theories and practices in school environments, exists as part of a process of program implementation and evaluation, produces theories that are capable of being applied in other environments, identifies the specific elements of a program that brought change, and ties specific elements of a program to the results (Design-based Research Collective, 2003). Design-based research has been suggested to be a particularly effective means of learning about teacher professional development for educational technologies (MacDonald, 2007; Mishra \& Koehler, 2006).

\section{The Professional Development Program}

Participants at the study site received IWBs for their classrooms beginning in the 2010-2011 school year. In an effort to encourage participants to integrate the IWBs in their instruction, administrators and teacher-leaders at the study site planned professional development opportunities for teachers to learn techniques for integrating their IWBs during instruction. The professional development program under study consisted of three components: one eight-hour in-service workshop in August of 2011, monthly skills seminars throughout the 2011-2012 school year on methods for integrating IWBs during instruction, and on-demand individualized support from teachers at the site who served as IWB mentors. The sustained, collaborative, and scaffolded professional development program was designed to enhance the technology self-efficacy of participants by increasing their technology acceptance and TPACK. This program was sustained throughout an entire school year, included structured opportunities for teacher collaboration, and scaffolded the instruction of new skills. Appendix A describes the core elements of the professional development program studied during this project. Table 1 displays the topics presented during the monthly skills seminar sessions. 
Table 1: Monthly skills seminar topics

\begin{tabular}{|l|l|}
\hline \multicolumn{1}{|c|}{ Skills Seminars } & \multicolumn{1}{c|}{ Topics } \\
\hline September - 9/19/11 & ActiveInspire Camera Function and Hyperlink Creation \\
\hline October - 10/17/11 & Student Engagement Devices - “Clickers” \\
\hline November - 11/14/11 & Student Project Collaboration With Prezi \\
\hline December - 12/19/11 & $\begin{array}{l}\text { Digital Interactive Resource Sharing Using The Professional Develop- } \\
\text { ment Blog Site }\end{array}$ \\
\hline January - 01/23/12 & Edmodo For Instruction and Assessment \\
\hline February - 02/20/12 & Digital Interactives For PSSA Preparation \\
\hline March - 03/19/12 & Integrating Technology Tools In The Curriculum \\
\hline
\end{tabular}

\section{Participants}

Forty-six fifth through eighth-grade teachers from a medium-sized rural school district in central Pennsylvania were invited to participate in this study. Forty-one of those teachers consented to participate in the current study. The participants ranged in age from twenty-three to sixty-one. Thirty of the participants were females and eleven participants were males. The participants' prior experience with IWBs in their classrooms ranged from zero to three years. All of the fortyone teachers at the study site participated in the monthly skills seminars and had access to IWB mentors as part of their prescribed professional development required by the superintendent of the district.

Twenty-two teachers at the selected site also elected to participate in an optional scaffolded professional development workshop presented in August of 2011. These participants are referred to as Group A in the present study. Nineteen teachers who did not elect to participate in the workshop, but did participate in the mandatory monthly skills seminars were also included in this study. These participants are referred to as Group B. Six participants were randomly selected from the study population to participate in the qualitative portion of the study. Teachers who participated in the professional development but declined to sign the informed consent form were excluded from the study. No vulnerable subject populations were included

\section{The Interactive Whiteboard Technology Self-Efficacy Survey}

The IWBTSE instrument was created to gather evidence of changes in technology self-efficacy among participants and to create an opportunity to compare the technology self-efficacy of teachers who participated in a scaffolded full-day professional development IWB training and those who did not. The IWBTSE instrument included five subscales: (a) perceived usefulness of IWBs, (b) perceived ease of use of IWBs, (c) IWB technology knowledge, (d) IWB technologicalpedagogical knowledge, and (e) IWB technological-content knowledge. The perceived usefulness and perceived ease of use subscales were modified from Davis's (1989) TAM. The technology knowledge, technological-pedagogic knowledge, and technological-content knowledge scales were modified from Mishra and Koehler's (2006) TPACK framework. Together, the subscales were designed to measure participants' IWB technology self-efficacy. Participants recorded their responses using a Likert scale. Their response possibilities included strongly agree, agree, neither agree or disagree, disagree, and strongly disagree. Appendix B presents the items on the

IWBTSE survey. 
Content validity was determined for the IWBTSE prior to its use during this study. This validation occurred first during a review by an expert panel. The expert panel included three faculty members of a College of Education at a regionally accredited university, each with a doctoral degree and not less than five years of experience in their positions. The expert panel reviewed the subscales and items from the instrument and helped to ensure they were comprehensive and measured their intended purpose. Further validation of the IWBTSE instrument occurred during a pilot study, conducted on July 16th, 2011. During the pilot, twenty-two doctoral students were administered the IWBTSE. Following the pilot study, a focus group was conducted with the pilot study participants during which participants were asked a series of questions aimed at ensuring the survey items were adequate in scope, specificity, and accuracy. This information was used by the expert panel to improve the validity of this instrument by altering the wording of several questions and removing two questions entirely from the instrument.

The internal reliability of the IWBTSE instrument was affirmed with the Cronbach's Alpha coefficient during the first administration of the survey to Group A participants. The Cronbach's Alpha coefficient was calculated for each of the instrument's subscales (i.e., perceived usefulness, perceived ease of use, technology knowledge) to ensure that items within each subscale were consistent with one another and that each subscale measured what it was intended to measure. Each of the items on the IWBTSE had satisfactory reliabilities with Cronbach's $\alpha=0.7$ or higher, indicating an acceptable level of internal reliability (Gliem \& Gliem, 2003). Table 2 identifies the Cronbach's Alpha coefficient for each of the subscales on the IWBTSE instrument.

\section{Table 2: Cronbach's $\alpha$ for subscales of the IWBTSE instrument}

\begin{tabular}{|l|c|c|}
\hline \multicolumn{1}{|c|}{ Subscale } & Cronbach's $\alpha$ & No. of items \\
\hline Perceived Usefulness & .84 & 5 \\
\hline Perceived Ease of Use & .80 & 6 \\
\hline Technology Knowledge & .89 & 5 \\
\hline Technological Pedagogical Knowledge & .74 & 7 \\
\hline Technological Content Knowledge & .82 & 6 \\
\hline
\end{tabular}

\section{Semi-Structured Participant Interviews}

Following the close of the professional development, six participants were randomly selected to receive semi-structured participant interviews, three from Group A and three from Group B. These interviews were recorded in the teachers' classrooms during their planning periods. The purpose of these interviews was to collect qualitative data about the teachers' experiences and opinions regarding the professional development program. The interviews began with a general question template; however, participants were encouraged to elaborate their responses or to share information regarding their reflections on the professional development treatment. Interviewees were each assigned a pseudonym and parts of their responses were transcribed to avoid their recognition through turn-of-phrase. Appendix $\mathrm{C}$ displays the core questions that formed the framework of the semi-structured participant interviews.

\section{Procedures}

This study was conducted in three phases. During the first phase, twenty-two participants in Group A completed the IWBTSE instrument then completed a day-long scaffolded professional development workshop in August of 2011. The nineteen participants in Group B did not participate in this workshop. Phase two occurred throughout the 2011-2012 school year. During this 
phase, both Group A and Group B participants joined in after-school professional development seminars focusing on integrating IWBs and related technologies into teachers' instruction. Participants also had on-demand access to support from other teachers serving as IWB mentors. Phase three occurred after the professional development program ended in May, 2012. During phase three, both Group A and Group B participants completed the IWBTSE instrument. Six participants, three each from Group A and Group B, were then randomly selected to participate in the semi-structured participant interviews.

\section{Analyses}

Research question one, Does participation in sustained, collaborative and scaffolded professional development affect the perception of usefulness, perception of knowledge, and technology selfefficacy regarding IWBs among participants?, was answered by comparing the results of the preand post-treatment administrations of the IWBTSE instrument to Group A. A paired-samples ttest was employed to conduct this analysis. Question two, Do differences exist in the technology self-efficacy for the use of IWBs among participants who joined in a day-long professional development workshop and monthly skills seminars and teachers who only participated in monthly skills seminars?, was answered by comparing the results of the post-treatment administration of the IWBTSE instrument to Group A and Group B. Question three, What do participants report regarding how their participation in sustained, collaborative, and scaffolded professional development for the IWB influenced their technology self-efficacy and their use of technology during instruction?, was answered using typological analysis of the post-treatment semi-structured participant interviews.

\section{Results}

\section{Research Question One Finding}

A paired samples $t$-test was employed to compare the pre- and post-experience IWBTSE samples

to identify the experience effects. The choice to utilize a paired samples $t$-test required the testing of two assumptions about the Pre-experience Interactive Whiteboard Technology Self-Efficacy sample (Pre-IWBTSE) and Post-experience Interactive Whiteboard Technology Self-Efficacy (Post-IWBTSE) sample. The arrangement of item responses on a Likert scale ensured that the data from the Pre- and Post-IWBTSE samples were interval. The Shapiro-Wilk Test was next employed to determine the normalcy of the samples. The $p$ value was found to be 0.18 on the Pre-IWBTSE and 0.48 on the Post-IWBTSE on the Shapiro-Wilk Test. Each of these values was above the $p=0.05$ threshold indicating the data for these samples were normal and parametric statistics were appropriate for these data.

The null-hypothesis for the paired-sample $t$-test, employed to answer research question one, was that there was no difference between the mean scores for the Pre-IWBTSE and Post-IWBTSE samples. The descriptive data that identified the changes in technology self-efficacy among the five subscales as recorded by the pre- and post-experience IWBTSE surveys for the sixteen participants in Group A who completed the pre- and post-experience IWBTSE surveys are displayed in Table 3. 
Table 3: Pre- and post-experience IWBTSE scores of Group A participants

\begin{tabular}{|l|c|c|c|}
\hline \multicolumn{1}{|c|}{ Measure } & N & Mean & SD \\
\hline Pre- Total Technology Self-Efficacy Score & 16 & 93.38 & 14.77 \\
\hline Post- Total Technology Self-Efficacy Score & 16 & 107.38 & 17.17 \\
\hline Pre- Perceived Usefulness & 16 & 19.38 & 2.60 \\
\hline Post- Perceived Usefulness & 16 & 20.00 & 3.01 \\
\hline Pre- Perceived Ease of Use & 16 & 17.75 & 4.28 \\
\hline Post- Perceived Ease of Use & 16 & 20.69 & 5.57 \\
\hline Pre- Technology Knowledge & 16 & 13.13 & 4.24 \\
\hline Post- Technology Knowledge & 16 & 17.63 & 3.96 \\
\hline Pre- Technological Pedagogical Knowledge & 16 & 28.06 & 3.68 \\
\hline Post- Technological Pedagogical Knowledge & 16 & 31.00 & 3.14 \\
\hline Pre- Technological Content Knowledge & 16 & 20.06 & 4.41 \\
\hline Post- Technological Content Knowledge & 16 & 23.06 & 3.91 \\
\hline
\end{tabular}

The paired samples $t$-test indicated a $p$ value of 0.01 . This value is below the $p=0.05$ threshold, indicating a rejection of the null hypothesis. The results of the paired-sample $t$-test demonstrated that the mean score for Post-IWBTSE samples was significantly higher than the mean score of the Pre-IWBTSE participants. Cohen's $d$ model (1988) was employed to determine the effect size. By dividing the mean (13.2) scores by the standard deviation (15.28), $d$ was calculated to be .86 which, according to Cohen's (1988) model, is a large effect. These results are illustrated in Table 4.

Table 4: Paired-sample t-test comparison of the pre-treatment and post-treatment IWBTSE scores for Group A participants

\begin{tabular}{|c|c|c|c|c|}
\hline df & Mean & SD & t & p \\
\hline 14 & 13.2 & 15.28 & 3.35 & 0.01 \\
\hline
\end{tabular}

\section{Research Question Two Finding}

An independent samples $t$-test was employed to conduct this analysis. The choice to utilize an independent samples $t$-test required the testing of several assumptions about the combined Group A and Group B post-IWBTSE sample. The arrangement of item responses on a Likert scale ensured the data from the combined Post-IWBTSE sample were interval. The $p$ value was .55 for the combined Post-IWBTSE on the Shapiro-Wilk Test of normality. This value was above the $p=0.05$ threshold indicating the data for these samples were normal. The results of the Levene's Test on the combined Post-IWBTSE indicated that the $p$ value was 0.73 . This was above the $p=0.05$ threshold indicating the sample variances were equal and parametric statistics were appropriate for these data.

The null hypothesis for the independent samples $t$-test, employed to answer research question number two, was that there was no difference in the mean post-treatment total IWB technology self-efficacy scores of Group A and Group B. The descriptive data that describe the differences in technology self-efficacy as recorded by the pre- and post-experience IWBTSE surveys for the twenty participants in Group A and the nineteen participants in Group B who completed the postexperience IWBTSE survey are displayed in Table 5. 
Table 5: Post-experience IWBTSE scores of Group A and Group B participants

\begin{tabular}{|l|c|c|c|}
\hline \multicolumn{1}{|c|}{ Measure } & N & Mean & SD \\
\hline Group A Total Technology Self-Efficacy Score & 20 & 111.50 & 16.36 \\
\hline Group B Total Technology Self-Efficacy Score & 19 & 106.95 & 13.89 \\
\hline
\end{tabular}

The independent samples $t$-test indicated a $\mathrm{p}$ value of 0.36 . This value is above the $\mathrm{p}=0.05$ threshold indicating the null hypothesis was not rejected. The results of the independent sample t-test demonstrated that the mean score for the Group A and Group B total IWB technology selfefficacy scores were not significantly different. These results are illustrated in Table 6.

Table 6: Independent-sample t-test comparison of the Post-treatment IWBTSE scores for Group A and Group B participants

\begin{tabular}{|c|c|c|c|}
\hline df & Mean & t & p \\
\hline 37 & 4.55 & 9.34 & 0.36 \\
\hline
\end{tabular}

\section{Research Question Three Finding}

The analysis of research question three was conducted using the typological-analytic process described by Hatch (2002). This analysis revealed three patterns among the participants' responses. These patterns include (1) participants reported more frequent and engaging uses of the IWB during instruction, (2) participants reported higher self-efficacy for IWB technology, (3) participants reported the sustained, collaborative, and scaffolded professional development aided in the progression of patterns one and two.

\section{Pattern 1}

During their interviews, five of the six participants made at least one statement indicating that they use technology more following the professional development treatment than they did before the program began. Statements made by one participant, Mike, are illustrative of this point. Before the professional development, he suggested that "I felt like it [his IWB] would just sit there and for the first year it pretty much did". Following the professional development, this same participant reported several rich and engaging uses of the IWB during instruction. According to Mike, "Now it's not even something you think about, you just kind of do it. It's nice having it in place there". Another participant, Anne, summarized her use of her IWB this way:

... We would play the game together up there first and then go over to the computer lab to try it as a class. From using the camera feature and learning how to import things into the board I am doing more. For example, they had homework the other day that they just bombed. I inputted their homework into the board and we worked through it together and they could see how things were supposed to go and then the light bulbs were coming on. In the past, I would have gone over the homework, but it wouldn't have been as meaningful. That came from the in-services and listening to people talk about how they used it.

\section{Pattern 2}

The second pattern suggested that participants enjoyed a higher degree of self-efficacy when using their IWBs following the professional development treatment. Anne's comments are illustrative of this point. Anne stated that before the professional development, "I definitely feel like I needed extra help with technology things. That's one of the things I notice with technology; if I 
do something at an in-service but don't do it again for another 3 weeks I don't remember how to do it". Later during her interview, Anne made statements that seemed to indicate she had come to identify the usefulness of the educational technologies introduced during the professional development. She also suggested that she had overcome some of the barriers to use that had impeded her early progress. These two items were theorized by Davis (1989) as being the key elements to developing and maintaining a high degree of self-efficacy. Supporting this point, Anne stated near the end of her interview, "I am also willing to give things a try in my classes with the kids and, if it bombs, I am willing to try it again later".

\section{Pattern 3}

The third pattern suggested that the professional development treatment influenced the positive changes in technology use and self-efficacy among the participants. According to another participant, Denise:

...I liked the fact that there was a little bit of instruction, then free time to use it. For me, if I don't sit down right away to try to use the tools I will probably forget them or not be as enthusiastic about it. We had quite a bit of time during the faculty meetings to actually work on making something.

In addition, Denise's interview indicated that the open-ended structure of the professional development program, coupled with the devotion of time to integrate the new tools and strategies during instruction, were important elements in the development of technology self-efficacy among the participants. This was confirmed later during her interview when, while referencing her preferences for professional development when learning new technologies, she said, "Definitely more freedom. I like having someone show me what is possible with the tools then allowing me to make it work for the concept I am teaching. I would have found something more structured to be a waste of time because I would have created something I probably wouldn't have used". Her experience connects the positive changes in technology self-efficacy and instructional use to the professional development treatment under study.

\section{Discussion}

The significant enhancements in technology self-efficacy found among Group A participants following their participation in the treatment supports the existing literature indicating the value of sustained, collaborative, and scaffolded professional development (Doppelt et al., 2009; Garet et al., 2001; Guskey \& Yoon, 2009; Walker et al., 2011). Group A participants were immersed in the professional development experience for a full school year and participated in a variety of seminars, formal and informal learning opportunities with their peers, and structured activities meant to gradually build more sophisticated instructional techniques using the boards. These elements were described in the literature to be efficacy-building features of effective professional development for IWBs (Jones \& Vincent, 2010; Lewin, Scrimshaw, Somekh, \& Haldane, 2009; Miller \& Glover, 2007) and it is likely that their inclusion in the professional development experience were important contributors to this outcome.

The findings from the comparison of the post-treatment results of Group A and Group B on the IWBTSE survey ran contrary to the expected results. It was posited that the full day professional development workshop would be an important factor in scaffolding the basic IWB technology skills for participants. Because Group A received this training and Group B did not, it was speculated that Group A would reach a higher sense of self-efficacy following the professional development program, however, this was not the case. There was not a statistically significant difference between Group A and Group B. 
Several factors might explain this finding. First, the structure and format of the day-long professional development workshop that Group A participants attended may not have significantly contributed to the development of technology self-efficacy. Tschannen-Moran \& McMaster (2009) suggested that "verbal persuasion, vicarious experiences, and even a limited mastery experience did not prove to be particularly powerful in creating the conditions to support implementation of a new instructional strategy when they took place in a large group setting" (p. 242), highlighting the importance of embedding professional development in relevant school contexts. This daylong training was held in the summer and in a large-group setting, out of the specific contexts in which teachers were expected to use the boards. Despite efforts to integrate efficacy-building measures into this portion of the professional development, it is possible that the structure of this portion of the professional development was ineffective. Similarly, the introductory nature of the day-long professional development workshop attended by Group A participants limited participants' abilities to demonstrate mastery of the IWBs and their functions among their peers. Mastery experiences and opportunities for peer-learning have been demonstrated to contribute to the development of participants' self-efficacy in professional development programs (Al-Awidi \& Alghazo, 2012).

A second potential explanation for this finding again relates to the differences between Group A and Group B participants. Due to the nature of the initial professional development workshop offered at the study site, these groups were not randomly selected. Group A participants elected to participate in the full day professional development workshops for their IWBs, while Group B participants chose other unrelated professional development offerings. Participants with a preexisting low degree of self-efficacy for technology may have been more likely to select a professional development track that offered more time working directly with the IWBs. The professional development workshop may have leveled the playing field among all the participants at the study site, allowing participants with low self-efficacy in Group A to build a robust sense of selfefficacy and catch up with the early-adopters and high-efficacy participants in Group B.

Though the professional development workshop did not affect a statistically significant difference in Group A's and Group B's technology self-efficacy, both groups registered a high degree of technology self-efficacy on the post-treatment IWBTSE survey. This finding was strengthened by the qualitative analysis of the semi-structured participant interviews during the analysis for research question three. Due to the complex environment at the study site and the impracticality of isolating the professional development experience as an independent variable it would have been very difficult to confirm a direct link to the professional development experience and the effects registered during the analysis of research questions one and two with only quantitative analysis methods. The qualitative analysis conducted during this study confirmed the powerful efficacy-building effects of collaborative learning and supported a key finding made by Fulton and Britton (2011) which suggested the importance of teacher collaboration as a central element of professional development for STEM teachers. It also confirms the findings of Doppelt et al. (2009) and Goddard et al. (2007) by indicating the value of collaborative in-service teacher learning structures. Each of the three patterns identified during this analysis supported the central finding of the study: that sustained, collaborative, and scaffolded professional development for the IWB assisted in the development of technology self-efficacy among in-service teachers.

\section{Limitations and Implications for Future Research}

This research utilized a design-based research paradigm (Design-Based Research Collective, 2003). The design-based research paradigm invites researchers to participate in the design and implementation of the professional development experience. During this study, my position as a peer teacher of the participants may have influenced their responses on the research instruments. Previously existing positive or negative opinions of me could have caused respondents to exag- 
gerate or underreport either the frequency they utilized the independent components of the professional development or changes in their technology self-efficacy. The misidentification of the professional development with professional evaluation may also have inclined participants to respond more negatively to survey items or to falsely inflate the frequency of interactive whiteboard use. Also, the duration of the study allowed external factors, beyond the professional development offerings for Groups A and B, to influence the participants' technology self-efficacy. Data collected during this study were used to identify correlational relationships between the professional development and changes in technology self-efficacy, TK, TPK, and TCK. This study was also limited to one medium-sized rural school. It featured a relatively small sample size; therefore its findings may not apply to other settings, technologies, or professional development programs.

The potential for inaccurate responses stemming from my association with the professional development was mitigated by appointing four IWB mentors who helped lead the scaffolded professional development workshop at the beginning of the school year, as well as the monthly skill seminar sessions during faculty meetings. Participants were encouraged to respond accurately through the maintenance of their anonymity during the study. All teachers were assigned an identification number and used this number when recording their responses on each survey instrument. Participants in the qualitative phase of the study were given a pseudonym to encourage genuine responses to the questions. I communicated the delineation between this professional development and the participant's own professional evaluation by distributing a voluntary consent letter that explained that each participants' responses on the quantitative instruments were considered in aggregate and that their responses to the qualitative or open ended survey items would remain anonymous.

The findings made during the analysis phase of this study inform the discussion how to best ready teachers to integrate technologies in the classroom, however, questions remain regarding the effects of professional development on teachers' technology self-efficacy and technology use. Since self-efficacy was theorized to be a predictor of a person's likelihood of performing a task in the future (Bandura, 1997), a follow-up study measuring participants' levels of self-efficacy for newly emerging tools like tablet computers and personalized learning platforms would prove to be very valuable. The discussion would also benefit from the findings of a similar study, conducted on a larger scale and over a longer period of time to measure changes in self-efficacy over time.

\section{Conclusion}

Collins and Halverson (2009) argued that the digital revolution has put pressure on educational institutions to radically transform how they communicate information to students. Thus far, most western education institutions have resisted this change and have instead adhered to the systems and processes that they were initially founded upon (Robinson, 2011). The sluggish rate of pro-

gress made by educational institutions in response to the new realities of the digital revolution has contributed to the widening income and education gaps registered in the United States since the 1980s (Golden \& Katz, 2008). Specifically, schools are not adequately preparing students with the skills they require to utilize evolving media technologies to communicate and collaborate (Jacobs, 2010) or contribute to the economy with new innovative technologies (Wagner, 2012), despite the fact that these elements have been designated and promoted as part of the International Society for Technology in Education's National Education Technology Standards for Students (International Society for Technology in Education, 2008). This reality serves as an impetus to reformers who seek to capitalize on the educational opportunities made possible by emerging technologies. 
By improving the quality of professional development offered to teachers for educational technologies, we can help them incorporate emerging classroom technology tools. According to Linda Darling-Hammond (2010), "Although there are some great teachers in every community, and some strong professional preparation and development programs sprinkled across the country, the landscape for supporters of quality teaching looks like Swiss cheese" (p. 194). The findings from this study suggest that sustained, scaffolded, and collaborative professional development may serve as a means of filling in the holes described by Darling-Hammond; assisting teachers in developing technology self-efficacy and supporting their ability to integrate new technology tools in their instruction.

\section{References}

Al-Awidi, H. M., \& Alghazo, I. M. (2012). The effect of student teaching experience on preservice elementary teachers' self-efficacy beliefs for technology integration in the UAE. Educational Technology Research and Development, 60(5), 923-941.

Bandura, A. (1997). Self-efficacy: The exercise of control. New York, NY: W.H. Freeman.

Berk, L.E., \& Winsler, A. (1995). Scaffolding children's learning: Vygotsky and early childhood education. Washington, DC: National Association for the Education of Young Children.

Brinkerhoff, J. (2006). Effects of a long-duration, professional development academy on technology skills, computer self-efficacy, and technology integration beliefs and practices. Journal of Research on Technology in Education, 39(1), 22-43.

Buckenmeyer, J. A. (2010). Beyond computers in the classroom: Factors related to technology adoption to enhance teaching and learning. Contemporary Issues in Education Research 3(4), 27-35.

Cantrell, S., \& Hughes, H. K. (2008). Teacher efficacy and content literacy implementation: An exploration of the effects of extended professional development with coaching. Journal of Literacy Research, 40(1), 95-127. doi:10.1080/10862960802070442

Cennamo, K., Ross, J., \& Ertmer, P. (2010). Technology integration for meaningful classroom use: A standards based approach. Belmont, CA: Wadsworth.

Cohen, J. (1988). Statistical power analysis for the behavioral sciences (2nd ed.). Hillsdale, NJ: Lawrence.

Collins, A., \& Halverson, R. (2009). Rethinking education in the age of technology: The digital revolution and schooling in America. New York, NY: Teacher's College Press.

Collins, A. \& Halverson, R. (2010). The second educational revolution: Rethinking education in the age of technology. Journal of Computer Assisted Learning, 26(1), 18-27. doi: 10.1111/j.13652729.2009.00339.x

Darling-Hammond, L. (2010). The flat world and education: How America's commitment to equity will determine our future. New York, NY: Teachers College Press.

Darling-Hammond, L., \& Richardson, N. (2009). Teacher learning: What matters? Educational Leadership, $66(5), 46$.

Davis, F. D. (1989). Perceived usefulness, perceived ease of use, and user acceptance of information technology. MIS Quarterly, 13(3), 319-339.

DeSantis, J. (2012). Getting the most from your interactive whiteboard investment: Three guiding principles for designing effective professional development. The Clearing House: A Journal of Educational Strategies, Issues, and Ideas, 85(2), 1-5.

Design-Based Research Collective. (2003). Design-based research: An emerging paradigm for educational inquiry. Educational Researcher, 32(1), 5-8.

Doppelt, Y., Schunn, C. D., Silk, E. M., Mehalik, M. M., Reynolds, B., \& Ward, E. (2009). Evaluating the impact of a facilitated learning community approach to professional development on teacher practice and student achievement. Research in Science \& Technological Education, 27(3), 339-354. 
DuFour, R. (2004). What is a "professional learning community"? Educational Leadership, 61(8), 6.

DuFour, R. (2011). Work together but only if you want to. Phi Delta Kappan, 92(5), 57-61.

Fulton, K., \& Britton, T. (2011). STEM teachers in professional learning communities: From good teachers to great teaching. New York, NY: National Commission on Teaching \& America's Future.

Garet, M. S., Porter, A. C., Desimone, L., Birman, B. F., \& Yoon, K. S. (2001). What makes professional development effective? Results from a national sample of teachers. American Educational Research Journal, 38(4), 915-945.

Gliem, J. A., \& Gliem, R. R. (2003, October). Calculating, interpreting, and reporting Cronbach's alpha reliability coefficient for Likert-type scales. Paper presented at the Midwest Research-to-Practice Conference in Adult, Continuing, and Community Education, Ohio State University, Columbus, $\mathrm{OH}$.

Goddard, Y. L., Goddard, R. D., \& Tschannen-Moran, M. (2007). A theoretical and empirical investigation of teacher collaboration for school improvement and student achievement in public elementary schools. Teachers College Record, 109(4), 877-896.

Golden, C., \& Katz, L.F. (2008). The race between education and technology. Cambridge, MA: Harvard College Press.

Guskey, T. R., \& Yoon, K. (2009). What works in professional development? Phi Delta Kappan, 90(7), 495-500.

Hall, G. E. (2010). Technology's Achilles heel: Achieving high-quality implementation. Journal of Research on Technology in Education, 42(3), 231-253.

Hall, G. E., \& Hord, S. M. (2010). Implementing change: Patterns, principles, and potholes. Boston, MA: Pearson Press.

Hanushek, E. A., \& Rivkin, S. G. (2010). Using value-added measures of teacher quality (Brief 9). Washington, DC: National Center for Analysis of Longitudinal Data in Education Research.

Hatch, J. A. (2002). Doing qualitative research in educational settings. Albany, NY: State University of New York Press.

Hill, H. C. (2009). Fixing teacher professional development. Phi Delta Kappan, 90(7), 470-477.

Hixon, E., \& Buckenmeyer, J. (2009). Revisiting technology integration in schools: Implications for professional development. Computers in the Schools, 26(2), 130-146. doi:10.1080/07380560902906070

Holden, H., \& Rada, R. (2011). Understanding the influence of perceived usability and technology selfefficacy on teachers' technology acceptance. Journal of Research on Technology in Education, 43(4), 343-367.

International Society for Technology in Education. (2008). The ISTE NETS and performance indicators for teachers. Retrieved from http://www.iste.org/Libraries /PDFs/NETS_for_Teachers_2008_EN.sflb.ashx

Jacobs, H. H. (Ed.). (2010). Curriculum 21: Essential education for a changing world. Alexandria, VA: ASCD.

Johnson, C. C., Kahle, J., \& Fargo, J. D. (2007). A study of the effect of sustained, whole-school professional development on student achievement in science. Journal of Research in Science Teaching, 44(6), 775-786.

Jones, A., \& Vincent, J. (2010). Collegial mentoring for effective whole school professional development in the use of IWB technologies. Australasian Journal of Educational Technology, 26(4), 477-493.

Lewin, C., Scrimshaw, P., Somekh, B., \& Haldane, M. (2009). The impact of formal and informal professional development opportunities on primary teachers' adoption of interactive whiteboards. Technology, Pedagogy \& Education, 18(2), 173-185. doi:10.1080/14759390902992592

Lyons, J., \& Plunckett, J. (2007). Multimedia histories: From the magic lantern to the internet. Exeter, UK: University of Exeter Press. 
MacDonald, R. (2007). Professional development for information communication technology integration: Identifying and supporting a community of practice through design-based research. Journal of Research on Technology in Education, 40(4), 429-445.

Measures of Effective Teaching Project. (2009). Learning about teaching: Initial findings from the measures of effective teaching project. Retrieved from http://www.metproject.org/downloads/Preliminary_Finding-Policy_Brief.pdf

Miller, D., \& Glover, D. (2007). Into the unknown: The professional development induction experience of secondary mathematics teachers using interactive whiteboard technology. Learning, Media and Technology, 32(3), 319-331.

Mishra, P., \& Koehler, M. J. (2006). Technological pedagogical content knowledge: A framework for teacher knowledge. Teachers College Record, 108(6), 1017-1054.

Musanti, S. I., \& Pence, L. (2010). Collaboration and teacher development: Unpacking resistance, constructing knowledge, and navigating identities. Teacher Education Quarterly, 37(1), 73-89.

Overbaugh, R., \& Lu, R. (2008). The impact of a NCLB-EETT funded professional development program on teacher self-efficacy and resultant implementation. Journal of Research on Technology in Education, 4l(1), 43-61.

Perry, B., Dockett, S., \& Harley, E. (2007). Preschool educators' sustained professional development in young children's mathematics learning [Special issue]. Mathematics Teacher Education \& Development, 8, 117-134.

Polly, D., \& Brantley-Dias, L. (2009). TPACK: Where do we go now? Techtrends: Linking Research \& Practice to Improve Learning, 53(5), 46-47. doi:10.1007/s11528-009-0324-4

Robinson, K. (2011). Out of our minds: Learning to be creative. West Sussex, UK: Capstone.

Rogers, E. M. (1962). Diffusion of innovations. New York, NY: Glencoe Free Press.

Sergiovanni, T. J. \& Starratt, R. J. (2006). Supervision: A redefinition. New York, NY: McGraw Hill.

Tschannen-Moran, M., \& McMaster, P. (2009). Sources of self-efficacy: Four professional development formats and their relationship to self-efficacy and implementation of a new teaching strategy. Elementary School Journal, 110(2), 228-24.

Venkatesh, V., Morris, M. G., Davis, G. B., \& Davis, F. D. (2003). User acceptance of information technology: Toward a unified view. MIS Quarterly, 27(3), 425-478.

Wagner, T. (2012). Creating innovators: The making of young people who will change the world. New York, NY: Simon and Schuster.

Walker, A., Recker, M., Robertshaw, M. B., Olsen, J., Leary, H., Lei, Y., \& Sellers, L. (2011). Integrating technology and problem-based learning: A mixed methods study of two teacher professional development designs. The Interdisciplinary Journal of Problem-Based Learning, 5(2), 70-94.

Wang, F., \& Hannafin, M. J. (2005). Design-based research and technology-enhanced learning environments. Educational Technology Research \& Development, 53(4), 5-23.

Wang, L., Ertmer, P. A., \& Newby, T. J. (2004). Increasing preservice teachers' self-efficacy beliefs for technology integration. Journal of Research on Technology in Education, 36(3), 231-250.

Whitehurst, G. (2010). Evaluating teachers: The important role of value-added. Washington, DC: Brookings Institution.

Yoon, K., Duncan, T., Lee, S., Scarloss, B., \& Shapley, K. L. (2007). Reviewing the evidence on how teacher professional development affects student achievement (Issues \& Answers Report, REL 2007No. 033). Washington, DC: US Department of Education, Regional Educational Laboratory Southwest. 


\section{Appendix A - Professional Development Program}

\section{Introduction Workshop Professional Development Overview}

The purpose of the introduction workshop was to build technical efficacy regarding the basic functions of the Interactive Whiteboard among participants. Emphasis was placed on ensuring all teachers could use the hardware and had access to ActivInspire software on their desktop computers. Basic functions were demonstrated and participants were encouraged to reflect on possible applications for the board in their classrooms. These functions included maintaining the equipment, calibrating the board, basic tool use, designing flipcharts, and finding pictures and videos to use in flipcharts on the web. The seminar lasted 7.5 hours. It culminated with each participant making their own five slide flipchart to use during their instruction.

Implementation: August, 2011

Facilitators: Director of Curriculum and Instruction, Program Coordinator (Researcher) and IWB mentors

\section{Skills Seminars Professional Development Overview}

IWB mentors conducted a skill seminar during a faculty meeting on the second Monday of every month for one half hour after school. These seminars were mandatory for all teachers at the Middle School. During some seminars, the mentor prepared one intermediate to advanced IWB tool to share with teachers. During the first ten minutes of these seminars, the mentor demonstrated the tool and ensured each teacher present has mastered its use. During the next ten minutes, teachers reflected with their peers on how the new tool could be applied to their lessons. During the last 10 minutes of the seminar, teachers applied the new skill in their own flipcharts. IWB mentors assisted teachers during this process. During other seminars, teachers divided into subject areas. During the first 15 minutes of the monthly skills seminar, teachers searched for web content that could be used to integrate the IWBs into instruction. During the second half of the session, teachers shared their findings with other members of their department.

Implementation: September, 2011 - April, 2012

Facilitators: Program Coordinator (Researcher) and IWB mentors

\section{Blog Site Professional Development Overview}

The program coordinator (researcher) also maintained a professional development blog site. The site was a collection of videos of the mentors and coordinator presenting IWB tools and directions for how to use specific interactive whiteboard functions. Teachers also uploaded resources to the website that they found and believed would be helpful to other teachers who taught their same subject.

Implementation: September, 2011 - April, 2012

Facilitators: Program Coordinator (Researcher)

\section{Mentor "Office Hours" Professional Development Overview}

Teachers designing lessons using the IWB require a level of "On Demand" support so that they could receive help for specific technology related questions. The Middle School had three teacher-mentors to fulfill this function. The mentors each held one "Office Hour" once a month, where teachers could come to have their IWB questions answered and could receive ideas for how to better integrate the IWB in their instruction. Mentors also assisted the program coordinator in developing and presenting the after school skill seminar sessions.

Implementation: September, 2011 - April, 2012

Facilitators: Program Coordinator (Researcher) and IWB mentors 


\title{
Appendix B - IWBTSE Survey Items
}

\author{
Perceived Usefulness
}

1. The interactive whiteboard can make it easier for teachers to hold their students' interest.

2. I am a more effective teacher because I have access to an interactive whiteboard.

3. Using an interactive whiteboard can make teaching easier.

4. My lessons are better because I use an interactive whiteboard.

5. Students can learn better when their teacher integrates an interactive whiteboard into their instruction.

\section{Perceived Ease of Use}

1. Integrating the interactive whiteboard in instruction is slow.

2. I feel frustration when teaching with my interactive whiteboard.

3. I feel confident that I can get my interactive whiteboard to do what I want it to do.

4. Using the interactive whiteboard limits my instruction.

5. I understand how my interactive whiteboard works.

6. Interactive whiteboard technology is easy to use during instruction.

\section{IWB Technology Knowledge}

1. I know how to set up, calibrate, and make basic adjustments to my interactive whiteboard.

2. My interactive whiteboard will function properly when I need it to.

3. I waste time struggling with interactive whiteboard preparation software. (Activinspire)

4. I have the knowledge I need to solve problems that might arise while using my interactive whiteboard.

5. I know how to use the tools and functions of my interactive whiteboard.

\section{IWB Technological-Pedagogical Knowledge}

1. I can think of ways to use my interactive whiteboard when introducing a new lesson.

2. I can think of ways to use my interactive whiteboard when summarizing or at the closure of a lesson.

3. I can think of skills or activities to model for students using my interactive whiteboard.

4. I will use the interactive whiteboard during instruction more in the future.

5. I have the skills to create engaging instructional activities using the interactive whiteboard.

6. I think about how I will use my interactive whiteboard while planning lessons, units, and assessments.

7. Students often physically touch my interactive whiteboard during my instruction.

\section{IWB Technological-Content Knowledge}

1. My interactive whiteboard helps me to include content-specific technologies in my lessons (software, video, audio, photographs).

2. I frequently (once a week or more) introduce content from the Internet to my classes using an interactive whiteboard.

3. I can think of digital interactives from the Internet I use during my lessons.

4. My interactive whiteboard makes it easier to teach my subject to students.

5. An interactive whiteboard is the most important piece of instructional technology in my classroom for teaching my subject to students.

6. My course includes more digital content because I have access to an Interactive Whiteboard. 


\section{Appendix C - \\ Semi-Structured Participant Interview Questions}

1. Describe your opinions of the interactive whiteboard before August of 2011.

a. Describe your concerns about your interactive whiteboard when it first arrived.

b. Describe how you thought you would use the interactive whiteboard before you received professional development for it?

2. Describe your current proficiency with your interactive whiteboard

a. Do you feel confident in your ability to get your interactive whiteboard to do what you want it to do today? Why or why not?

b. Are there any ways that you use your interactive whiteboard now that came from ideas received during the interactive whiteboard professional development? If so, describe one of these uses.

c. Do your skills with the interactive whiteboard help you to be a more effective classroom teacher? Why or why not?

3. Describe your current proficiency with other classroom technologies like Edmodo or Prezi.

a. How confident are you in your ability to learn new instructional technologies?

b. Do your skills with instructional technologies make you a better teacher?

4. Which parts of the professional development program did you find helpful?

a. The professional development program took place over a longer period of time and was more focused on one topic than other types of professional development. Would you prefer having more professional development opportunities structured this way? Why or why not?

b. Which elements of the professional development program did you find the most (and least) helpful?

c. Would you have preferred the professional development give you more freedom to use the IWB how you see fit, or would you rather have been given more guidance about specific instructional uses of your board?

5. Is there anything that was not asked during this interview, or on the surveys, that you feel would be valuable to the researcher? 


\section{Biography}

Joshua DeSantis is an Assistant Professor of Education at York College of Pennsylvania where

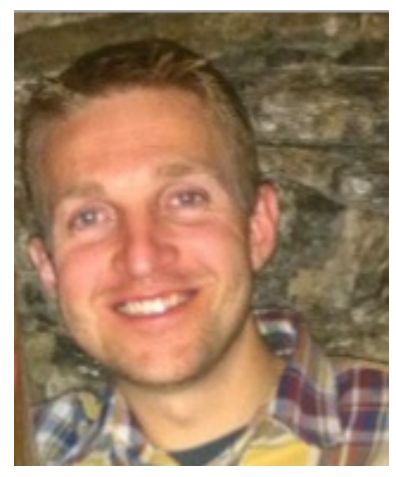
he teaches courses in education technology and curriculum development. His research interests include technology-supported teaching pedagogies and social studies education. He earned his B.A. in Social Studies Education and M.A. in Applied History at Shippensburg University of Pennsylvania and his D.Ed. in Curriculum and Instruction from Indiana University of Pennsylvania. Before he began his higher education career he taught Social Studies at Susquenita Middle School near Harrisburg, PA. This paper reports the findings from a dissertation project. Joshua is eternally grateful to his wife - Danielle, fatherDavid, mother - Deborah, and chairperson - Dr. Rotigel for their support. 